\title{
Analisis pendapatan budidaya ayam broiler dengan menggunakan herbal kunyit
}

\author{
Income analysis of broiler chicken cultivation by using turmeric herbs
}

\author{
Nurjannah Bando ${ }^{1}$, Fitriana Akhsan ${ }^{1 *}$ dan Anita Sari ${ }^{1}$ \\ ${ }^{1}$ Program Studi Agribisnis Peternakan, Politeknik Pertanian Negeri Pangkajene Kepulauan \\ ${ }^{*}$ Corresponding author: fitriana.akhsan@yahoo.com
}

Diterima tanggal 12 Agustus 2019, Disetujui tanggal 30 Agustus 2019

\begin{abstract}
Abstrak
Penelitian ini bertujuan untuk untuk mengetahui pengaruh perbedaan pendapatan pemeliharaan ayam broiler antara penggunaan herbal kunyit melalui pakan dan aplikasi pada air minum. Penelitian dilakukan mulai bulan Juli sampai Agustus 2019 di kampus Politeknik Pertanian Negeri Pangkep. Sebanyak 96 ekor DOC dipelihara selama 21 hari, masing-masing 8 ekor untuk setiap unit percobaan. Penelitian ini menggunaan rancangan acak lengkap (RAL) terdiri dari 3 perlakuan dan 4 kali ulangan, dengan susunan perlakuan yaitu $\mathrm{P} 0=$ Pemeliharaan menggunakan pakan dan air minum konvensional; $\mathrm{P} 1=$ Pemeliharaan dengan menggunakan herbal kunyit sebanyak $1 \%$ dari jumlah pakan dan $\mathrm{P} 2=$ Pemeliharaan dengan menggunakan herbal kunyit dengan aplikasi pada air minum sebanyak $1 \%$ dari jumlah air minum. Pendapatan kegiatan budidaya ayam broiler dihitung menggunakan rumus : Pd (Pendapatan $)=$ TR $($ Total Penerimaan) - TC (Total biaya). Hasil penelitian menunjukkan bahwa pendapatan budidaya ayam broiler menggunakan herbal kunyit melalui pakan tidak berbeda nyata dengan aplikasi pada air minum. Namun jika dibandingkan pemeliharaan secara konvensional, pemeliharaan ayam dengan menggunakan herbal kunyit cenderrung meningkatkan pendapatan $(P<0,05)$. Rata-rata pendapatan tertinggi diperoleh pada perlakuan P2 yaitu Rp 84.578,-/8 ekor, kemudian P1 sebesar Rp 73.165,- /8 ekor dan terendah pada perlakuan P0 yaitu $\mathrm{Rp} 31.495,-/ 8$ ekor.
\end{abstract}

Kata kunci: pendapatan, ayam broiler, herbal, kunyit

\begin{abstract}
This study aims to determine the effect of differences in maintenance income between broiler chickens between the use of turmeric herbs through feed and applications in drinking water. The study was conducted from July to August 2019 at the Pangkep State Polytechnic of Agriculture. A total of 96 DOC tails are maintained for 21 days, each of $8 \mathrm{DOC}$ for each unit of trial. The study uses a complete random design (CRD) consisting of 3 treatments and 4 repeated, with the composition of the treatment of $\mathrm{PO}=$ Maintenance using conventional feed and drinking water; $\mathrm{P} 1$ = Maintenance using turmeric herbs as much as $1 \%$ of the amount of feed and P2 = Maintenance using turmeric herbs is drinking water as much as $1 \%$ of the amount of drinking water. To calculate the income of broiler chickens cultivation activities, can be calculated with the formula: Pd (Income) = TR (Total revenue) - TC (Total cost). The results showed that the income of broiler chicken cultivation using turmeric herbs through feed was not significantly different from the application in drinking water. However, when compared to conventional maintenance, raising chickens using turmeric herb tends to increase income $(P<0.05)$. The highest average income was obtained in the P2 treatment, namely Rp. 84,778 / 8 broiler chicken, then P1 was Rp. 73,165, - / 8 broiler chicken and the lowest in the P0 treatment was Rp. 31,495, - / 8 broiler chicken.
\end{abstract}

Keywords: income, broiler chickens, herbs, turmeric

\section{PENDAHULUAN}

Sumber protein asal ternak yang paling banyak di konsumsi yaitu daging ayam. Daging ayam merupakan produk peternakan yang paling terjangkau dibandingkan dengan produk daging yang lainnya. Harga yang murah serta distribusi produk yang meluas menyebabkan 
daging ayam merupakan produk peternakan yang paling diminati oleh konsumen. Dengan dasar ini pula sektor peternakan ayam broiler jauh lebih pesat perkembangannya di bandingkan dengan komoditas yang lainnya. Biaya pemeliharaan yang relatif lebih kecil menjadi salah satu alasan lembaga penelitian untuk mengembangkan berbagai teknologi dalam usaha pemeliharaan ayam broiler tersebut.

Dewasa ini dapat disaksikan kemajuan teknologi dibidang perunggasan khususnya broiler telah menghasilkan capaian yaitu pemeliharaan dilakukan hanya selama 21 hari untuk produksi ayam broiler siap potong. Rasyaf (2004) menyatakan bahwa di Indonesia ayam broiler sudah dapat dipasarkan pada usia lima sampai enam minggu dengan bobot hidup antara 1,3 sampai $1,6 \mathrm{~kg}$ per ekor. Capaian tersebut tentu saja mendorong peningkatan produksi yang sangat pesat. Keadaan tersebut diusahakan dengan berbagai perlakuan, salah satunya dengan menggunakan antibiotik yang dijadikan sebagai hormon pemacu pertumbuhan. Selain itu pemeliharaan yang menggunakan antibiotik juga dimaksudkan sebagai metode dalam mempertahankan kesehatan ternak. Penggunaan antibiotik tersebut memang secara nyata dapat memacu produksi namun penggunaannya juga akan menghasilkan beberapa kekurangan. Kekurangan penggunaan bahan kimia dalam budidaya ayam broiler yaitu ditemukannya residu-residu bahan kimia yang akan mengancam kesehatan konsumen.

Pemerintah telah banyak menangani temuan berbagai residu bahan kimia pada tubuh ayam broiler. Peraturan-peraturan pemerintah telah dikeluarkan untuk mengatur batas ambang penggunaan antibiotik dalam pakan ternak. Undang-Undang No 41 Tahun 2014 tentang Peternakan dan Kesehatan Hewan jelas tercantum larangan penggunaan imbuhan pakan berupa antibiotik. Batas penggunaan antibiotik dalam pakan ayam broiler diatur, sehingga konsumen tidak dirugikan. Batas ambang ini sebelumnya telah diteliti sehingga, dengan penggunaan batasan tersebut sudah bisa dipastikan tidak lagi meninggalkan residu yang berpeluang terkonsumsi oleh konsumen.

Peraturan pemerintah tentang larangan penggunaan antibiotik dalam pakan sebaliknya akan menekan pertumbuhan ayam broiler. Selain itu, pengurangan penggunaan vaksin juga tentu saja akan mengancam kesehatan ayam broiler. Dampak positif dari peraturan ini yaitu jaminan kesehatan konsumen terhadap residu bahan kimia. Namun, di lain pihak akan menimbulkan dampak negatif terhadap laju pertumbuhan ayam broiler. Hal ini tentu saja akan mengancam perkembangan industri di bidang perunggasan khususnya ayam broiler. Solusi untuk menangani masalah yang saling tumpang tindih ini, yaitu penggunaan feed additive herbal dalam pakan ayam broiler. Penggunaan pakan herbal dimaksudkan untuk menggantikan peran antibiotik dalam memelihara kesehatan ternak ayam broiler. Salah satu herbal yang paling mungkin digunakan yaitu kunyit (curcuma longa dan temulawak (Curcuma xanthorrhiza). Penggunaan kunyit dapat diaplikasikan melalui pakan maupun air minum. Peneliti telah menemukan berbagai efek positif dalam penggunaan herbal kunyit dalam pemeliharaan ayam broiler. Kandungan zat aktif kurkumin dapat berfungsi sebagai antibakteri, penambah nafsu makan dan kecernaan bahan pakan. Zat aktif kurkumin yang diberikan pada ayam broiler mempengaruhi tingkat konsumsi, pertambahan berat badan dan nilai konversi (Sutaji 2012). Selain itu pertumbuhan jamur dapat dihambat oleh kandungan zat aktif xantorizol yang terdapat pada temulawak (Purwanti 2008). Sehingga, penggunaan herbal dalam pakan ayam broiler dapat menjamin kesehatan konsumen serta mempertahankan laju pertumbuhan broiler.

Penggunaan pakan herbal belum banyak diketahui oleh peternak ayam broiler. Pengetahuan akan manfaat dan efisiensi penggunaan pakan herbal juga belum dimiliki oleh peternak, sehingga inovasi ini belum dilakukan oleh peternak secara intensif. Analisis pendapatan akan memberikan gambaran tentang berapa besar keuntungan yang akan diperoleh dalam suatu usaha. Menurut Soeharjo dan Patong (1973), dalam analisis pendapatan diperlukan dua keterangan pokok yaitu keadaan penerimaan dan pengeluaran selama jangka waktu yang ditetapkan. Tujuan analisis pendapatan adalah untuk menggambarkan keadaan sekarang dan keadaan yang akan datang dari kegiatan usaha. Dengan kata lain analisis pendapatan 
bertujuan untuk mengukur keberhasilan suatu usaha. Analisis pendapatan pemeliharaan ayam broiler dengan pemberian pakan herbal akan menjadi pertimbangan layak atau tidaknya inovasi ini diterapkan dalam masyarakat peternak. Analisis pendapatan juga akan menjadi salah satu rujukan peternak untuk menjalankan usaha ayam broiler dengan aplikasi herbal dalam pakan. Apabila peternak telah mengetahui efisiensi dan efektifitas penggunaan pakan herbal, maka kesenjangan antara kebutuhan dunia industri serta urgensi kesehatan konsumen dapat diselesaikan.

Penelitian ini bertujuan untuk untuk mengkaji perbedaan pendapatan pemeliharaan ayam broiler antara penggunaan herbal melalui pakan dengan aplikasi pada air minum serta pemeliharaan ayam broiler secara konvensional.

\section{BAHAN DAN METODE}

\section{Waktu dan Lokasi Penelitian}

Penelitian ini dilaksanakan selama 2 bulan. Dimulai pada bulan Juli 2019 hingga bulan Agustus 2019 di Kampus Politeknik Pertanian Negeri Pangkajene Kepulauan, Pangkep

\section{Rancangan Penelitian}

Penelitian ini dilaksanakan terdiri dari dua tahap. Tahap 1 pertama yaitu pemeliharaan dan tahap 2 pengambilan data.

\section{Tahap 1}

Budidaya ayam broiler dimulai dengan pemeliharaan DOC sebanyak 96 ekor, masingmasing 8 ekor untuk setiap unit percobaan. Penelitian ini menggunaan rancangan acak lengkap (RAL) terdiri dari 3 perlakuan dan 4 kali ulangan, dengan susunan perlakuan sebagai berikut:

$$
\begin{aligned}
\mathrm{P} 0= & \text { Pemeliharaan menggunakan pakan } \\
& \text { dan air minum konvensional } \\
\mathrm{P} 1= & \text { Pemeliharaan dengan menggunakan } \\
& \text { herbal kunyit melalui pakan } \\
\mathrm{P} 2= & \text { Pemeliharaan dengan menggunakan } \\
& \text { herbal kunyit melalui air minum. }
\end{aligned}
$$

\section{Tahap 2}

Tahap pengambilan data dilakukan selama penelitian yaitu data semua biaya produksi, mulai dari persiapan pemeliharaan, pemeliharaan sampai dengan pengambilan data penjualan.

\section{Populasi dan Sampel Penelitian}

Populasi dalam penelitian ini adalah semua ayam yang dipelihara selama penelitian, sebanyak 96 ekor yang terdiri dari 3 perlakuan dan 4 ulangan. Sampel dalam penelitian diambil dari semua populasi yang dipelihara.

\section{Jenis dan Sumber Data}

1. Jenis Data

Jenis data yang digunakan pada penelitian ini bersifat kualitatif dan kuantitatif, yaitu data yang diperoleh dalam bentuk wawancara dan angka angka (numeric) dari hasil kuisioner

2. Sumber Data

Sumber data yang digunakan dalam penelitian ini: 1) data primer yaitu data yang diperoleh langsung dari responden. 2) data sekunder yaitu data yang diperoleh dari sumber lain seperti data dokumentasi usaha budidaya ayam broiler.

\section{Teknik Pengumpulan data}

Teknik pengumpulan data yang digunakan dalam penelitian ini yaitu Observasi. Observasi dilakukan dengan cara melakukan pengamatan dan pengambilan data langsung pada lokasi penelitian budidaya ayam broiler.

\section{Metode dan Alat analisis}

Data yang diperoleh dari hasil observasi diolah dan ditabulasi. Kemudian data dianalisis dengan menggunakan metode analisis pendapatan dan diolah dengan model pendekatan ekonometri dan dijelaskan secara metode deskriptif. Untuk menghitung pendapatan dari kegiatan budidaya ayam ras pedaging, dapat dihitung dengan rumus :

$$
P d=T R-T C
$$

Keterangan :

$\mathrm{Pd}$ : total pendapatan atau keuntungan yang diperoleh pada pemeliharaan ayam broiler (rupiah/unit percobaan )

TR : total revenue atau penerimaan yang diperoleh pada pemeliharaan ayam broiler (rupiah/unit percobaan)

TC : biaya yang dikeluarkan pada pemeliharaan ayam broiler (rupiah/unit percobaan) (Soekartawi), 1995). 


Analisis R/C ratio adalah rasio
penerimaan atas biaya yang
menunjukkanbesarnya tambahan penerimaan
yang diperoleh dari setiap rupiah yang
dikeluarkan dalam produksi. $R / C$ ratio
menujukkan berapa besar tambahan
penerimaan yang diperoleh sebagai manfaat di
setiap rupiah yang dikeluarkan. Makin besar
R/C makin baik usahatani tersebut. Untuk
mengetahui tingkat keberhasilan usaha,
digunakan rumus sebagai berikut:

R/C Ratio Total $=\frac{R}{C}$

Keterangan:

$\mathrm{R}=$ Total penerimaan

$\mathrm{C}=$ Total biaya usahatani
Untuk mengetahui pengaruh perlakuan terhadap peubah yang diukur, data yang diperoleh diuji dengan sidik ragam (ANOVA) dengan bantuan software SPSS. Jika perlakuan memperlihatkan pengaruh nyata, maka dilanjutkan dengan uji wilayah berganda (Duncan) untuk mengetahui perbedaan antara perlakuan (Gaspersz, 1994).

\section{HASIL DAN PEMBAHASAN}

Total penerimaan, pendapatan dan $\mathrm{R} / \mathrm{C}$ rasio budidaya ayam broiler dengan menggunakan herbal kunyit berbeda nyata $(P<0,05)$ dan lebih tinggi di bandingkan dengan budidaya secara konvensional. Biaya tetap, biaya variabel dan total biaya pemeliharaan tidak berbeda $(P>0,05)$ antara pemeliharaan secara konvensional dengan pemeliharaan menggunakan herbal kunyit (Tabel 1).

Tabel 1. Total penerimaan, total biaya, pendapatan dan $\mathrm{R} / \mathrm{C}$ rasio budidaya ayam broiler dengan menggunakan herbal kunyit.

\begin{tabular}{lrrr}
\hline \multirow{2}{*}{ Parameter } & \multicolumn{3}{c}{ Perlakuan } \\
\cline { 2 - 4 } & \multicolumn{1}{c}{$\mathrm{P} 0$} & $\mathrm{P} 1$ & \multicolumn{1}{c}{$\mathrm{P} 2$} \\
\hline Total Penerimaan (Rp/8 ekor) & $228.375^{\mathrm{a}}$ & $269.900^{\mathrm{b}}$ & $281.000^{\mathrm{b}}$ \\
Total Biaya (Rp/8 ekor) & $196.880^{\mathrm{a}}$ & $196.735^{\mathrm{a}}$ & $196.422^{\mathrm{a}}$ \\
Biaya Tetap (Rp/8 ekor) & $27.148^{\mathrm{a}}$ & $27.148^{\mathrm{a}}$ & $27.148^{\mathrm{a}}$ \\
Biaya Variabel (Rp/8 ekor) & $169.733^{\mathrm{a}}$ & $169.587^{\mathrm{a}}$ & $169.274^{\mathrm{a}}$ \\
Pendapatan (Rp/8 ekor) & $31.495^{\mathrm{a}}$ & $73.165^{\mathrm{b}}$ & $84.578^{\mathrm{b}}$ \\
R/C Rasio & $1,16^{\mathrm{a}}$ & $1,37^{\mathrm{b}}$ & $1,43^{\mathrm{b}}$ \\
\hline
\end{tabular}

${ }^{\bar{a}, \mathrm{~b}}$ Superskrip dengan huruf berbeda pada baris yang sama menunjukkan berbeda nyata. $(\mathrm{P}<0,05)$. $\mathrm{P} 0=\mathrm{Pemeliharaan}$ menggunakan pakan dan air minum konvensional, $\mathrm{P} 1$ = Pemeliharaan dengan menggunakan herbal melalui pakan, $\mathrm{P} 2=$ Pemeliharaan dengan menggunakan herbal melalui air minum.

Pemeliharaan ayam broiler menggunakan herbal kunyit secara nyata $(P<0,05)$ meningkatkan pendapatan. Pendapatan budidaya ayam broiler menggunakan herbal kunyit melalui pakan dan air minum lebih tinggi jika dibandingkan dengan budidaya secara konvensional menggunakan vaksin. Pendapatan yang tinggi tersebut dipengaruhi oleh total penerimaan yang juga tinggi pada pemeliharaan menggunakan herbal kunyit baik melalui pakan maupun melalui air minum. Kadarsan (1995) menerangkan bahwa pendapatan adalah selisih antara penerimaan total perusahaan dengan pengeluaran. Untuk menganalisis pendapatan diperlukan dua keterangan pokok, yaitu keadaan pengeluaran dan penerimaan dalam jangka waktu tertentu.
Rasyaf (2002) menambahkan bahwa pendapatan adalah sejumlah uang yang diperoleh setelah semua biaya variabel dan biaya tetap tertutupi.

Total biaya pemeliharaan antara semua perlakuan tidak berbeda nyata $(P>0,05)$. Hal ini disebabkan oleh karena biaya tetap maupun biaya variabel juga sama antara semua perlakuan. Firwiyanto (2008) menyatakan bahwa komponen biaya yang dikeluarkan peternak pada kegiatan budidaya usaha ternak ayam broiler terbagi atas biaya variabel dan biaya tetap.

Nilai rasio $\mathrm{R} / \mathrm{C}$ pada penelitian ini antara 1,16 sampai 1,43. Nilai Rasio $R / C$ menggambarkan bahwa budidaya ayam broiler pada penelitian ini mendapatkan penerimaan 
sebesar Rp 1,16 sampai 1,43 untuk setiap satu rupiah biaya yang dikeluarkan. Semakin tinggi nilai rasio $\mathrm{R} / \mathrm{C}$ dalam suatu usaha tani, maka akan semakin besar keuntungan yang diperoleh. Nilai tersebut lebih tinggi daripada nilai rasio $\mathrm{R} / \mathrm{C}$ pada penelitian yang dilakukan oleh Taslukha (2007) pada usaha peternakan ayam broiler Sunan Kudus Farm yaitu 1,05.

Tingginya penerimaan usaha ayam broiler yang menggunakan herbal kunyit juga disebabkan karena harga jual ayam herbal lebih tinggi dibandingkan dengan ayam konvensional. Harga jual ayam broiler dengan sistem pemeliharaan konvensional yaitu $\mathrm{Rp}$ $35.000 / \mathrm{kg}$ bobot hidup, sedangkan ayam herbal yaitu mencapai $40.000 / \mathrm{kg}$ bobot hidup. Kesadaran masyarakat pada makanan sehat menyebabkan konsumen lebih memilih ayam yang dipelihara dengan pakan atau minuman herbal untuk dikonsumsi.

Penggunaan herbal kunyit melalui pakan maupun air minum menghasilkan pendapatan yang tinggi. Hal tersebut disebabkan karena herbal berupa kunyit akan memperbaiki kondisi kesehatan ternak ayam. Ayam yang sehat akan menghasilkan produksi yang maksimal dengan tingkat kematian yang rendah. Bobot badan ayam broiler yang mendapat asupan herbal kunyit melalui pakan dan air minum juga lebih tinggi. Oleh karena itu, penggunaan herbal kunyit secara langsung dapat meningkatkan pendapatan pada usaha budidaya ayam broiler. Ardiansya, dkk.,(2012) menyatakan bahwa pemberian ramuan herbal baik dalam bentuk cair maupun serbuk mampu membunuh bakteri pada saluran usus dengan cara melisiskan racun - racun yang menempel pada dinding usus. Leboh lanjut dikemukakan oleh Sutaji (2012), bahwa penggunaan feed additive herbal dapat dipakai untuk menggantikan antibiotik. Bahan feed additive herbal yang terdiri dari temulawak (Curcuma xanthorrhiza) dan kunyit (Curcuma longa). Kandungan zat aktif kurkumin dapat berfungsi sebagai antibakteri, penambah nafsu makan dan kecernaan bahan pakan. Zat aktif kurkumin yang diberikan pada ayam broiler mempengaruhi tingkat konsumsi, pertambahan berat badan dan nilai konversi.

Pendapatan budidaya ayam broiler dengan penggunaan herbal kunyit melalui pakan tidak berbeda nyata $(P>0,05)$ dengan aplikasi melalui air minum. Namun jika dilihat secara angka, pemberian herbal kunyit melalui air minum lebih tinggi jika di bandingkan melalui pakan. Hal ini disebabkan oleh karena herbal kunyit yang diberikan melalui air minum berasal dari perasan kunyit mentah sehingga harganya lebih murah dibandingkan dengan kunyit bubuk. Perasan kunyit juga lebih cepat teserap dibandingkan dengan kunyit bubuk yang diberikan melalui pakan. Selain itu penggunaan kunyit melalui air minum lebih efisien dan kemungkinan untuk tumpah lebih sedikit. Menurut Gusna (2017), berdasarkan beberapa penelitian mengemukakan bahwa ramuan herbal yang diberikan melalui air minum ternyata memberi respon yang baik terhadap pertumbuhan dan stamina ayam, serta bau kotoran ayam di sekitar kandang berkurang.

\section{KESIMPULAN}

Hasil penelitian ini menunjukkan bahwa tidak ada perbedaan yang nyata antara pendapatan budidaya ayam broiler menggunakan herbal kunyit melalui pakan dan air minum, namun terdapat kecenderungan pendapatan budidaya ayam broiler menggunakan herbal kunyit lebih tinggi dibandingkan dengan budidaya secara konvensional.

\section{UCAPAT TERIMA KASIH}

Terima kasih disampaikan kepada ketua dan staff PPPM Politeknik Pertanian Negeri Pangkep yang menjadi penyedia dana penelitian serta seluruh civitas akademik Program Studi Agribisnis Peternakan yang telah memfasilitasi penulis untuk melakukan penelitian ini.

\section{DAFTAR PUSTAKA}

Ardiansyah. W, Agustina, L. dan Tandi, E.J. 2012. Pemberian ramuan herbal pada broiler yang diinfeksi Salmonella pullorum terhadap histopatologi usus halus dan hati. Fakultas Peternakan Universitas Hasanuddin. Makassar.

Firwiyanto, M. 2008. Analisis pendapatan dan tingkat kepuasan peternak terhadap pelaksanaan kemitraan ayam broiler(kasus kemitraan peternak plasma rudi jaya ps Sawangan, depok. Skripsi. 
Fakultas Pertanian. Institut Pertanian Bogor.

Gasperz, V. 1994. Metode Rancangan Percobaan. CV. Armico, Bandung.

Gusna, B. 2017.Pengaruh ramuan herbal labio1 terhadap kualitas interior telur ayam ras petelur strain isa brown. Skripsi. Fakultas Peternakan Universitas Hasanuddin, Makasaar.

Kadarsan, H. W. 1995. Keuangan Pertanian dan Pembiayaan Perusahaan Agribisnis. Gramedia Pustaka Utama. Jakarta Murtidjo, B.A. 2006. Pedoman Meramu Pakan Unggas. Kanisius. Yogyakarta.

Purwanti S. 2008. Kajian efektifitas pemberian kunyit, bawang putih dan mineral zink terhadap performa, kadar lemak, kolesterol dan status kesehatan broiler. Skripsi. Fakultas Kedokteran Hewan. Institut Pertanian Bogor, Bogor.
Rasyaf, M. 2002. Beternak Ayam Pedaging. Edisi Revisi. Penebar Swadaya. Jakarta.

Rasyaf, M. 2004. Makanan Ayam Broiler. Jakarta: Penebar Swadaya.

Soeharjo dan Patong. 1973. Sendi-sendi Pokok Usaha Tani. Departemen IImu-ilmu Sosial Ekonomi. Fakultas Pertanian Bogor, Bogor.

Soekartawi. 1995. Alaisis Usaha Tani. Universitas Indonesia, Jakarta.

Sutaji. 2012. Pengaruh metode dan dosis pemberian temulawak (Curcuma xanthorriza roxb) terhadap performa broiler. J Cendikia. 10:23-30.

Taslukha. S.M. 2007. Analisis Pendapatan Usaha Ternak Ayam Broiler "Sunan Kudus Farm" di Unit Farm Jasinga dan Gunung Bunder Kabupaten Bogor Jawa Barat. Skripsi. Fakultas Peternakan. Institut Pertanian Bogor, Bogor. 